\title{
Arboreality and Diet in Pacific Long-tailed Snakes, Enulius flavitorques (Squamata: Dipsadidae), and a Potential Adaptive Hypothesis for Egg Attendance in Honduran Leaf-toed Geckos, Phyllodactylus palmeus (Squamata: Phyllodactylidae)
}

Tom W. Brown ${ }^{1}$, Matthijs P. van den Burg${ }^{2}$, Daisy. F. Maryon ${ }^{1,3}$, and Cristina Arrivillaga ${ }^{1}$

${ }^{1}$ Kanahau Utila Research and Conservation Facility, Isla de Utila, Honduras (browntb@outlook.com)

${ }^{2}$ University of Amsterdam, Amsterdam, the Netherlands

${ }^{3}$ University of South Wales, Pontypridd, United Kingdom

Photographs by the senior author.

$\mathrm{T}^{\mathrm{h}}$ he Pacific Long-tailed Snake, Enulius flavitorques (Cope 1868), is a wide-ranging species currently listed by Chaves et al. (2016) as being of Least Concern on the IUCN Red List. The species is distributed on the Pacific versant from Jalisco, Mexico, to Panama, and on the Atlantic versant in Chiapas, Mexico, Honduras, and from Costa Rica and central Panama to Colombia and toward northwestern Venezuela at elevations of $0-1,300 \mathrm{~m}$ asl (Solórzano 2004; Köhler 2008). In Honduras, the species has been reported from numerous localities (McCranie 2011; Solis et al. 2014), including Isla de Utila. The island of Utila is located in the Honduran Department of Islas de la Bahía (Bay Islands), where it is the westernmost island of the three major Bay Islands (Utila, Roatan, Guanaja) and part of the Cayos Cochinos Archipelago (McCranie et al. 2005).

Three species in the genus Enulius have been recorded from Honduras; all are little-studied and typically regarded as secretive, nocturnal, and semi-fossorial species. They occur in a range of habitat types that include wet forest, dry forest, coastal vegetation, and wet meadow/grassland (Köhler 2008).

McCranie and Orellana (2014) reported a single individual of $E$. flavitorques from Utila, using a photographic voucher to confirm its presence on the island. The populations of this species on Utila could be interesting from an evolutionary perspective, considering that McCranie and Köhler (1999) described two endemic species (E. bifoveatus and $E$. roatanensis) from the neighboring islands of Guanaja and Roatan without including a genetic sample from Utila in their analysis. A study further addressing the origins and routes from which these island populations stemmed, while determining the rate of speciation and morphological and genetic divergence would be most informative and could reveal a new endemic species of Enulius on Utila. As the species from the neighboring Bay islands are currently listed on the IUCN Red List as Critically Endangered (E. biofoeatus; Wilson et al. 2014) and Endangered (E. roatanensis; Wilson et al. 2013), if a new endemic population occurs on Utila, we expect that, based largely on its restricted distribution, it would qualify for Critically Endangered status.

Köhler (2008) described the diet of E. flavitorques as consisting predominantly of termites and ants, whereas Scott (1983) and de Queiroz and Rodríguez-Robles (2006) provided evidence that these snakes specialize in feeding on reptilian eggs. The latter contention is further supported by morphological studies that suggest that the enlarged rear teeth of $E$. flavitorques are used to perforate the shells of reptilian eggs (Solórzano 2004). On Utila, McCranie et al. (2005) reported an individual that was found $35 \mathrm{~cm}$ deep in sand next to a clutch of eggs of a Central American Rainbow Lizard (Cnemidophorus ruatanus), which it might have intended to eat (McCranie 2011). More recently, in Costa Rica, Solórzano and Mora (2017) observed E. flavitorques perforating and feeding on captive Green Iguana (Iguana iguana) eggs, providing definitive photographic evidence that these small snakes are able to consume reptilian eggs of considerable size, and also suggesting this species might consume eggs of marine turtles, 
other lizards, and snakes. On Utila alone, the diet of E. flavitorques could include the eggs of nearly 30 reptilian species that have been reported from the island (e.g., Powell 2003).

\section{Arboreality and Diet of Enulius flavitorques}

At 2045 h on 1 May 2017 adjacent to the Kanahau (KURCF) facility $\left(16.119383^{\circ} \mathrm{N}, 86.884989^{\circ} \mathrm{W}\right.$; WGS84), we observed an adult $E$. flavitorques at $2.3-2.8 \mathrm{~m}$ above the ground entering a termite nest in the fork of a large broadleaf tree (Fig. 1). Further investigation revealed a communal egg clutch of the Honduran Leaf-toed Gecko (Phyllodactylus palmeus) in a crevice between the bark and the termite nest. We saw one adult gecko (which escaped) and counted 26 small eggs (ca. $11 \mathrm{~mm}$ in length) and shell remains, suggesting that this was a frequently used multi-maternal nesting site for this endemic species of gecko.

From April to August 2017, we observed six other E. flavitorques on separate nocturnal occasions between 1900 and $2100 \mathrm{~h}$ within $1 \mathrm{~km}$ of the KURCF. One individual was on a workbench on the upper floor inside the facility (ca. $4 \mathrm{~m}$ above the ground), where eggs of the invasive Asian House Gecko (Hemidactylus frenatus) previously had been found. Two snakes were foraging at heights of approximately $1.3 \mathrm{~m}$ and $40 \mathrm{~cm}$ above the ground within large porous volcanic rock outcrops at the entrance to "Robinson Crusoe's Cave" adjacent to the facility. The remaining three individuals were on the ground in open ground habitat or on paths or roads at elevations of $0-74 \mathrm{~m}$ asl; sites were near broadleaf palm forest, an agricultural pasture, and in sandy coastal vegetation about
$15 \mathrm{~m}$ from the Pumpkin Hill beachfront (a locality known for nesting marine turtles and iguanas). Two of those individuals were captured and measured to provide basic morphometric data (though one individual was missing part of its tail), having snout-vent lengths (SVL) of 250 and $260 \mathrm{~mm}$, tail lengths of 69 and $15 \mathrm{~mm}$, total length of 319 and 275 $\mathrm{mm}$, and weights of 3.6 and $6 \mathrm{~g}$. These fall well within the maximum total length of $495 \mathrm{~mm}$ known for E. flavitorques, but seem more consistent with those of $321 \mathrm{~mm}$ and 346 $\mathrm{mm}$ listed for the island populations of E. bifoveatus and $E$. roatanensis, respectively (Köhler 2008).

Our observations are interesting in that $E$. flavitorques was thought to be a terrestrial and predominantly detritus dwelling, semi-fossorial or burrowing species (e.g., McCranie et al. 2005). Facultative use of arboreal habitats while foraging has been described for other terrestrial and presumably fossorial snakes (e.g., Keller and Heske 2000). Additionally, Sheehy et al. (2016), in a comparison of 226 snake species (Enulius not included), found a strong correlation between tail length and arboreal behavior, with long tails often adapted by species that climb or spend considerable time above ground, suggesting that Enulius (commonly known as "long-tailed snakes") are somewhat adapted for an arboreal lifestyle (e.g., Robertson et al. 2007).

Although we did not observe consumption of reptilian eggs, we believe the incident of arboreal foraging provided support for suggestions that $E$. flavitorques is able to locate reptilian eggs using olfactory senses (Solórzano and Mora 2017) and that the $P$. palmeus eggs were the reason for the

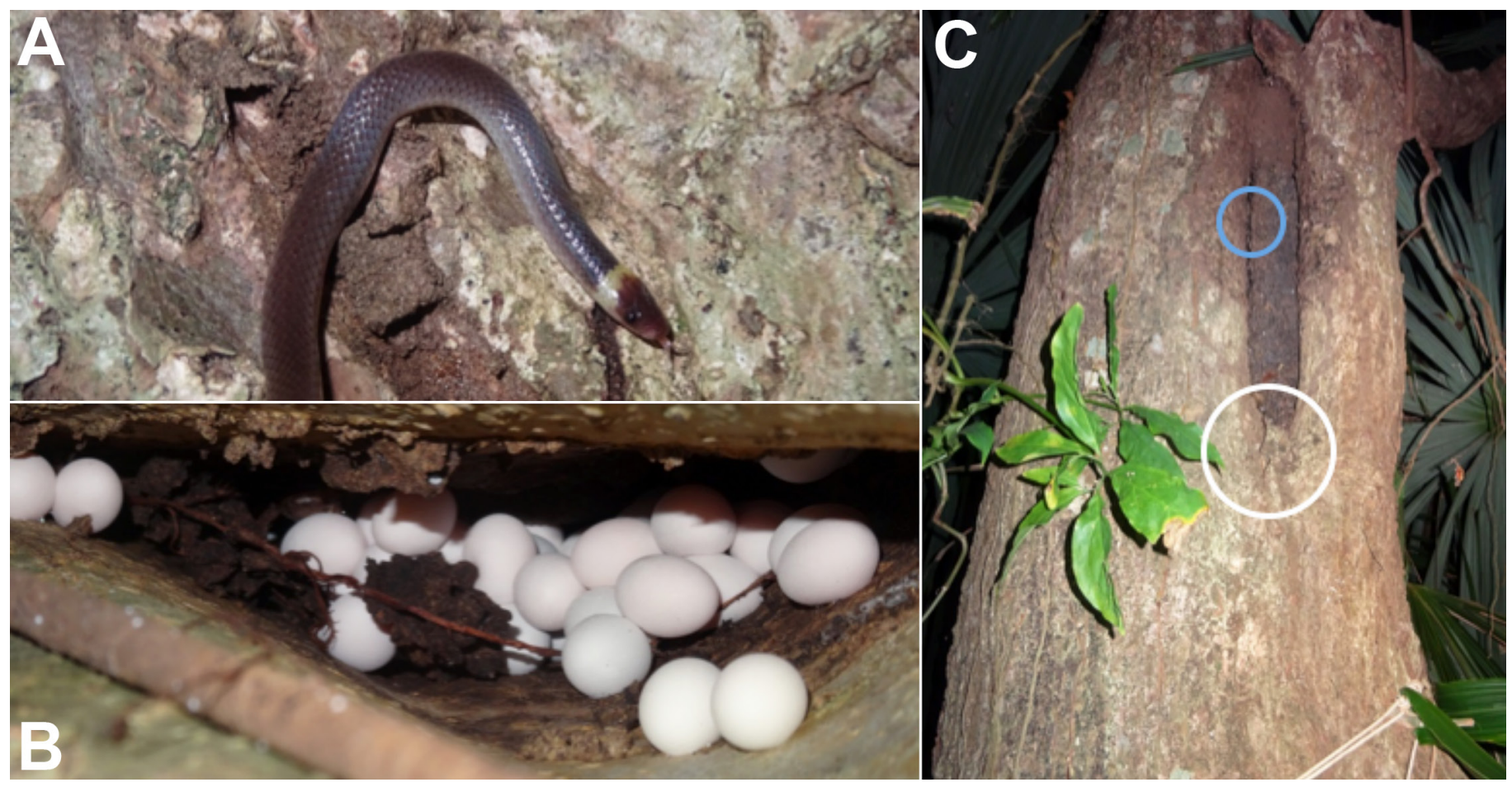

Fig. 1. Arboreality in Enulius flavitorques (A), with the presumed intention of predating on a multi-maternal clutch of Phyllodactylus palmeus eggs (B). The snake was $2.3 \mathrm{~m}$ above the ground (white circle in C); the egg clutch was behind the termite nest $2.8 \mathrm{~m}$ above the ground (blue circle in C). 
snake's presence. On the other hand, without the investigation of the termite nest, that observation could be interpreted as support for a diet of termites (i.e., Köhler 2008), although numerous reptiles, including snakes, lizards, and some turtles, are known to deposit eggs in termite and ant nests (e.g., Knapp and Owens 2008; Vitt and Caldwell 2013).

A dietary specialization on reptilian eggs could have arisen as a consequence of encountering eggs in termite and ant nests while engaged in egg deposition. Robertson et al. (2007) encountered a clutch of five eggs of Enulius sclateri in Costa Rica while excavating a fallen tree hollow, which prior to falling and at the presumed time of laying was 16.4 $\mathrm{m}$ above the ground. One proposed explanation by these authors was that "prey interactions could underlie arboreal oviposition, placing adults and/or hatchlings near a potential food source," presumably referring to the arboreal eggs of other reptiles. Nevertheless, such an observation of facultative arboreality in Enulius supports the suggestion that these putatively fossorial snakes could be exploiting a wider range of microhabitats than typically considered.

\section{Communal Nesting in Phyllodactylus palmeus}

We observed four additional communal nests of $P$. palmeus within and behind arboreal termite nests in broadleaf/palm forest and 11 more in the crevices, bark peels, and hollows of Fig Trees (Ficus sp.), Gumbo-limbo Trees (Bursera simaruba), dead Coconut Palms (Cocos nucifera), and volcanic coralline limestone rocks at heights of $1.2-3.7 \mathrm{~m}$ above the ground. Reports of communal nesting in $P$. palmeus are limited to a brief mention (from Utila) in Köhler (2008). Nicholson et al. (2012) noted that P. palmeus on the Cayos Cochinos produced several clutches, typically of two eggs, throughout the year, while also misinterpreting comments by McCranie and Hedges (2013b) regarding the local extirpation of $P$. palmeus in edificarian habitats around Utila Town, thereby inadvertently reporting the extinction of $P$. palmeus on Utila. The majority of the multi-maternal nests we observed contained more than ten eggs (suggesting that more than five females contributed ova) and had one to four attending adults present both during the day and night (Fig. 2). Although we did not observe any parental care, clutch attendance by adults could distract or deter potential predators (e.g., Graves and Duvall 1995; Mateo and Cuadrado 2012).

Our opportunistic observations of 16 communal nests suggest that parental attendance at $P$. palmeus communal nesting sites could be an adaptive defensive behavior designed to deter egg-raiding predators such as species of Enulius. Additional support for this hypothesis is provided by the fact that all Bay Island populations of Phyllodactylus ( $P$. palmeus on Utila, Roatan, Cayos Cochinos and $P$. paralepis on Guanaja; McCranie and Hedges 2013a) have been sympatric with populations of Enulius (E. flavitorques on Utila, Cayos Cochinos, E. roatanensis on Roatan, and E. bifoveatus on Guanaja; McCranie and Köhler 1999) for some time. Recognizing that communal nesting in reptiles and specifically in the infra-order Gekkota has been widely documented (e.g., Doody et al. 2009), we tentatively suggest that a dietary specialization on reptilian eggs by species of Enulius could be responsible for the multi-maternal nests and associated egg attendance and presumptive guarding behavior in these endemic island populations of Phyllodactylus geckos.

\section{Acknowledgements}

We sincerely thank Kanahau Utila Research \& Conservation Facility for the foundation and support from which to perform herpetological research on Utila. Special thanks go to the Kanahau research team, managing directors Steve Clayson and Andrea Martinez, as well as our local field guides Nahun Molina, Joxan Orlando Ayala, and all of the assisting volunteers from 2017. Additional thanks go to Gunther Köhler for his advice and publishing recommendations regarding this manuscript.

Biological research and collection permits (Resolución DE-MP-054-2017 - Dictamen técnico ICF-DVS-169-2017;
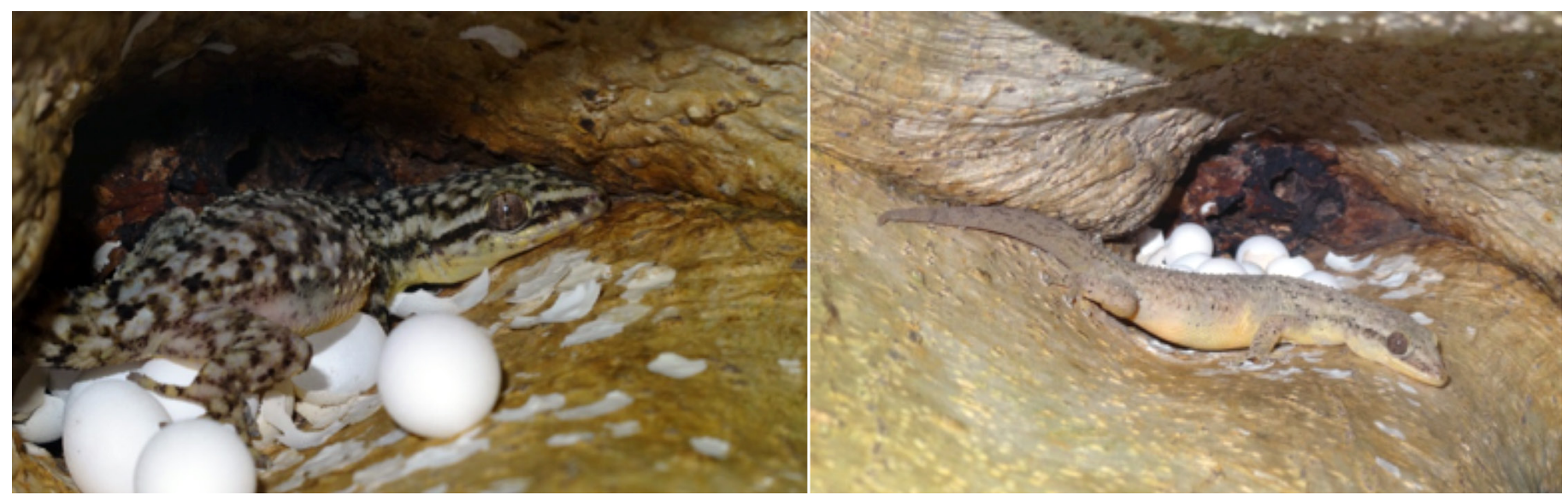

Fig. 2. Two communal nesting sites of Phyllodactylus palmeus, with preliminary observations of parental attendance; a behavioral adaptation that might offer a rudimentary form of defense against egg-raiding predators such as Enulius flavitorques. 
Dictamen técnico DAP-068-2017) for the project "Conservación de los reptiles y anfibios de Utila, Honduras" were issued to Daisy Maryon and Tom Brown of Kanahau (KURCF) by General Director Misael León and General Secretary Gudit Mariel Muñoz of the Instituto Nacional de Conservación y Desarrollo Forestal, Áreas Protegidas y Vida Silvestre (ICF), Tegucicalpa, Honduras.

\section{Literature Cited}

Chaves, G., O. Flores-Villela, L.W. Porras, M. Sasa, A. Ortega, W. Schargel, and G. Rivas. 2016. Enulius flavitorques. The IUCN Red List of Threatened Species 2016: e.T197484A2489055.

Cope, E.D. 1868. Sixth contribution to the herpetology of tropical America. Proceedings of the Academy of Natural Sciences of Philadelphia 20: 305-313.

de Queiroz, A. and J.A. Rodríguez-Robles. 2006. Historical contingency and animal diets: The origins of egg eating in snakes. The American Naturalist 167: 684-694.

Doody, J.S., S. Freedberg, and J.S. Keogh. 2009. Communal egg-laying in reptiles and amphibians: Evolutionary patterns and hypotheses. Quarterly Review of Biology 84: 229-252.

Graves, B.M. and D. Duvall. 1995. Aggregation of squamate reptiles associated with gestation, oviposition, and parturition. Herpetological Monographs 9: 102-119.

Keller, W.L. and E.J. Heske. 2000. Habitat use by three species of snakes at the Middle Fork Fish and Wildlife Area, Illinois. Journal of Herpetology 34: 558 564

Knapp, C.R. and K.A. Owens. 2008 Nesting behavior and the use of termitaria by the Andros Iguana (Cyclura Cyclura cychlura). Journal of Herpetology 42: $46-53$.

Köhler, G. 2008. Reptiles of Central America. 2nd ed. Herpeton, Offenbach, Germany.

Mateo, J.A. and M. Cuadrado. 2012. Communal nesting and parental care in Oudri's Fan-Footed Gecko (Ptyodactylus oudrii): Field and experimental evidence of an adaptive behavior. Journal of Herpetology 46: 209-212.

McCranie, J.R. and G. Köhler. 1999. Two new species of colubrid snakes of the genus Enulius from Isla de la Bahia, Honduras. Caribbean Journal of Science 35: 14-22.

McCranie, J.R., L.D. Wilson, and G. Köhler. 2005. Amphibians and Reptiles of the Bay Islands and Cayos Cochinos, Honduras. Bibliomania!, Salt Lake City, Utah, USA.

McCranie, J.R. 2011. The Snakes of Honduras: Systematics, Distribution, and Conservation. Contributions to Herpetology, Volume 26. Society for the Study of Amphibians and Reptiles, Ithaca, New York, USA.

McCranie, J.R. and S.B. Hedges. 2013a. A new species of Phyllodactylus (Reptilia, Squamata, Gekkonoidea, Phyllodactylidae) from Isla de Guanaja in the Honduran Bay Islands. Zootaxa 3694: 51-58.

McCranie, J.R. and S.B. Hedges. 2013b. A review of the Cnemidophorus lemniscatus group in Central America (Squamata: Teiidae), with comments on other species in the group. Zootaxa 3722: 301-316.

McCranie, J.R. and L.V. Orellana. $2014 \mathrm{New}$ island records and updated nomenclature of amphibians and reptiles from the Islas de la Bahía, Honduras. Herpetology Notes 7: 41-49.

Nicholson, D.J., C. Hassal, and J.A. Frazier. 2015. Comparison of a native and non-native insular reptile species. Journal of Tropical Ecology 31: 563-566.

Powell, R. 2003. Species profile: Utila's reptiles. Iguana 10: 36-38.

Robertson, J.M., C.L. Cardelús, and M.I. Williams. 2007. Arboreal oviposition site in the fossorial snake, Enulius sclateri. Herpetological Review 38: 466-467.

Scott, N.J. 1983. Leptotyphlops goudotii (Culebra Gusano, Worm Snake, Blind Snake), p. 406. In: D.H. Janzen (ed.), Costa Rican Natural History. The University of Chicago Press, Chicago, Illinois, USA.

Sheehy, C.M., J.S. Albert, and H.B. Lillywhite. 2016. The evolution of tail length in snakes associated with different gravitational environments. Functional Ecology 30: 244-254.

Solis, M.J., M.R. Espinal, and C. O'Reilly. 2014. Distribution notes. Enulius flavitorques (Cope, 1869). Mesoamerican Herpetology 1: 292.

Solórzano, A. 2004. Serpientes de Costa Rica: Distribución, Taxonomía e Historia Natural / Snakes of Costa Rica: Distribution, Taxonomy, and Natural History. Instituto Nacional de Biodiversidad (INBio), Santo Domingo de Heredia, Costa Rica.

Solórzano, A. and B. Mora. 2017. Enulius flavitorques (Cope, 1869). Feeding behavior. Mesoamerican Herpetology 4: 428-431.

Wilson, L.D., J.H. Townsend, and I. Luque. 2013. Enulius roatenensis. The IUCN Red List of Threatened Species 2013: e.T203508A2766810.

Wilson, L.D., J.H. Townsend, and I. Luque. 2014. Enulius bifoveatus. The IUCN Red List of Threatened Species 2014: e.T203507A2766803.

Vitt, L.J. and J.P. Caldwell. 2013. Herpetology. An Introductory Biology of Amphibians and Reptiles. Fourth Edition. Academic Press, San Diego, California, USA (see Chapter 4. Reproduction and Life Histories, pp. 117-155). 